\title{
The Experimental Works of Stu Campbell: The Use of New Media in Creating Online Comics
}

\begin{abstract}
Literature does not need to be solely confined to text, but can be accompanied by moving images, animation, sound, music, as well as a multi-linear narrative, which has become easier to integrate due to the use of hypertext and augmented reality (AR) technology. One author who readily uses such innovations is Stu Campbell, more widely known by his alias, Sutu. Aside from being a writer, Campbell is also an interactive designer and illustrator who combines art and technology in order to produce unique and experimental works. Campbell is inspired by multiple genres and formats through which he addresses poignant themes, such as memory and its loss, the imminent passage of time, as well as the meaning of identity and reality in our increasingly digital and fast-paced environment. Therefore, this paper discusses the selected works of Stu Campbell in the context of their experimental and technological nature drawing on Paola Trimarco's discussion of "affordances," a term originally derived from psychologist James L. Gibson, denoting the opportunities and limitations in certain environments. The works discussed are the following: Modern Polaxis, a multilinear comic in the form of a private journal which depends on AR technology to advance its narrative, Nawlz, a cyberpunk webcomic created on a horizontal interactive digital canvas, and These Memories Won't Last, a semi-autobiographical webcomic which incorporates music, sound and animation.
\end{abstract}

Keywords: webcomics, new media, Stu Campbell, comics, experimental literature, AR technology

\section{Eksperymentalna twórczość Stu Campbella. Użycie nowych mediów w tworzeniu komiksów online}

\begin{abstract}
Abstrakt: Literatura nie musi ograniczać się wyłącznie do tekstu, ale może towarzyszyć jej ruchomy obraz, animacja, dźwięk, muzyka, a także wieloliniowa narracja, która stała się łatwiejsza do zintegrowania dzięki wykorzystaniu hipertekstu i technologii rozszerzonej rzeczywistości (AR). Jednym z autorów, który chętnie korzysta z takich innowacji, jest Stu Campbell, szerzej znany pod pseudonimem Sutu. Oprócz bycia pisarzem Campbell jest także projektantem interaktywnych aplikacji i ilustratorem, który łączy sztukę i technologię, tworząc unikalne, eksperymentalne utwory. Campbell inspiruje się wieloma gatunkami i formatami o poruszającej tematyce, takiej jak pamięć i jej utrata, nieuchronny upływ czasu, a także zna-
\end{abstract}


czenie tożsamości i rzeczywistości w naszym, coraz bardziej cyfrowym i narzucającym szybkie tempo, środowisku. Dlatego w niniejszym artykule omówiono wybrane prace Stu Campbella w kontekście ich eksperymentalnego i technologicznego charakteru, odwołując się do refleksji Paoli Trimarco na temat „afordancji”, terminu wywodzącego się z dorobku psychologa Jamesa L. Gibsona, a oznaczającego możliwości i ograniczenia w określonych środowiskach. Artykuł omawia Modern Polaxis, wielowierszowy komiks w formie prywatnego dziennika, którego narracja opiera się na technologii AR, Nawlz, cyberpunkowy komiks internetowy stworzony na płaskim, interaktywnym, cyfrowym ,płótnie”, oraz These Memories Won't Last, na wpół autobiograficzny komiks internetowy, zawierający muzykę, dźwięk i animację.

Słowa kluczowe: webkomiksy, nowe media, Stu Campbell, komiksy, literatura eksperymentalna, technologia AR

$* * *$

The comic is a widely recognized medium that is made up of text and images. Renowned comic artist Will Eisner describes comics as "sequential art," which he sees as a "means of creative expression, a distinct discipline, an art and literary form that deals with the arrangement of pictures and images to narrate a story or dramatize an idea". ${ }^{1}$ However, due to the arrival of the Internet and the new media associated with it, the comic medium became influenced by digital technology; it took on an online form, widely referred to as the webcomic. ${ }^{2}$

Webcomics allow authors to experiment with a medium that predominately exists in printed form, enhancing it with select digital features. The following paper chooses to focus on three such webcomics by author and illustrator Stuart "Stu" Campbell: Modern Polaxis, Nawlz and These Memories Won't Last, which incorporate features like music, animation, sound effects and atypical panel arrangements. Stu Campbell creates experimental webcomics that intertwine with digital technology. This is not a gimmick, but rather it is a way of meaningfully interconnecting technology with the work itself. Therefore, within this paper, the experimental use of digital features that emerge from the new media will be emphasized, whilst considering the comic medium and its relationship with its form. Furthermore, the paper will draw attention to how the chosen works use technological enhancements and the ways in which these features influence the titles in question.

\section{The Comic Medium and Its Form: The Printed and The Digital}

It is important to address what constitutes a comic in a general terms before venturing into a deeper discussion about webcomics. An understanding of a comic's base form entails juxtaposed imagery and text in deliberate sequence. Confined to variations of the panel, these are then often separated by a "gutter," constituting a break or a gap. Naturally, this understanding cannot be universally applied to each comic. Indeed, in the simplest example, many comics do not have text at all.

1 W. Eisner, Comics and Sequential Art, Tamarac 1985, p. 4.

2 The term "webcomic" is an umbrella term for comics existing online. There are variations of online comics, which will be discussed further in the paper. 
Nevertheless, such a definition emphasizes the importance of sequential imagery in comics.

Definitions that confirm this notion can be found in works by Scott McCloud, ${ }^{3}$ Will Eisner ${ }^{4}$ and Thierry Groensteen. ${ }^{5}$ In his definition, McCloud includes the term "juxtaposed pictorial and other images in deliberate sequence", ${ }^{6}$ allowing for the absence of text within a comic. On the other hand, Eisner's older definition talks about "a montage of both word and image," where a reader needs to interpret both visually and verbally. ${ }^{7}$ Finally, Groensteen sees comics as a "preponderantly visual language in which text plays a subordinate role". ${ }^{8} \mathrm{He}$ describes the comic medium as an intricate system where semiotics plays a vital role in interpretation. ${ }^{9}$

As mentioned above, the definition of a comic is one that can be discussed at length due to the "ensemble of productive mechanisms of meaning"10 that the medium includes. Therefore, for the purposes of this paper, the matter of the form of comics will be primarily discussed. While comics are made up of the visual and often aided by the verbal, they have appeared in many forms throughout history. In Understanding Comics, McCloud provides historical insight into what he calls "comics' spectacularly varied past"; 11 for instance, he presents the medieval Bayeux Tapestry as an early, 70-meter long example of the comic medium, as well as a variety of works ranging from the eighteenth to the early twentieth century. Examples include William Hogarth's A Harlot's Progress, published in 1731 as plate engravings, and Rodolphe Töpffer's mid-nineteenth century comics, said to be one of the precursors of the modern comic strip. ${ }^{12}$ Here, McCloud cites the popularization of print as an important event in the development of the comic form, ${ }^{13}$ introducing as it did the confines of panels, borders and pages. McCloud's rather wide presentation of various comic forms has met with criticism; for instance, Beaty describes it as too generalizing, consequently ignoring older analyses of the form. ${ }^{14}$ On the other hand, Groensteen (2012) sees McCloud's efforts as a desperate attempt to legitimize comics lacking "theoretical sophistication". ${ }^{1516}$

Regardless, his work encapsulates the notion of how much the comic form has undergone change. Groensteen emphasizes this as well when describing different forms of publication for comics, where panels and the images and text contained within them are subjected to "reassembly" depending on the change of form, e.g.

${ }^{3}$ S. McCloud, Understanding Comics, New York 1993, p. 9.

${ }^{4}$ W. Eisner, op. cit., p. 8.

5 T. Groensteen, The System of Comics, Mississippi 2007, pp. 12-27.

${ }^{6}$ S. McCloud, Understanding..., op. cit., p. 9.

7 W. Eisner, op. cit., p. 9.

${ }^{8}$ T. Groensteen, op. cit., p. viii.

${ }^{9}$ Ibid., p. 2.

${ }^{10}$ Ibid.

${ }^{11}$ S. McCloud, Understanding..., op. cit., p. 21.

${ }^{12}$ Ibid., p. 17.

${ }^{13}$ Ibid., p. 15.

${ }_{14}$ B. Beaty, Comics versus Art, Toronto 2012, pp. 31-32.

${ }^{15}$ Examples of such criticism can be found in Bart Beaty's Comics versus Art (2012) and even in Groensteen's The System of Comics (2012).

16 T. Groensteen, op. cit., p. vii. 
a newspaper, a book or an album. ${ }^{17}$ Furthermore, Groensteen takes care to note that such changes have a profound effect on the meaning of a comic. If employed incorrectly, this can cause a loss. ${ }^{18}$ As such, it can be deduced that the comic medium relies on the ever-changing forms that are often tied to shifting eras, trends and inventions. In Comics and Sequential Art, Eisner draws attention to this as well, mentioning early comic forms from the sixteenth, seventeenth, and eighteenth centuries and describing how comics evolved into their modern printed form. ${ }^{19}$ Notable within the modern form of the comic are graphic novels. These may or may not have panels, and they might employ lettering as a form of imagery; for example, they could feature a dripping font to simulate falling blood or rain. ${ }^{20}$

The appearance and development of comics into their online counterparts can be connected to their inherent transmediality - a term which derives from Henry Jenkins' Convergence Culture and his concept of transmedia storytelling. ${ }^{21}$ In simplified terms, transmediality is connected to the appearance of e.g. works or phenomena spanning a variety of non-specific mediums; they can be realized in various ways due to the rise of contemporary multimedia. Tomasz Żaglowski expands Jenkins' understanding of transmediality, noting that the cultural aspect should be emphasized, as then: "Transmediality becomes . . the act of making a specific use of a specific text, while at the same time respecting. . . cognitive, economic and narrative patterns". ${ }^{22}$ It is for this reason that Żaglowski singles out comics as a suitable exploration of transmediality, ${ }^{23}$ agreeing with Rippl and Etter. ${ }^{24}$ This suitability is connected to comics' intermedial combination of word and image: "In fact, there is something at the very core of the comic book, viewed as both a semiotic and conceptual pattern, that builds upon the transmedial characteristics of the 'crossing' paradigm". ${ }^{25}$ The crossing paradigm Żaglowski alludes to here is in reference to "the crossing of the semiotic codes of image and word", alongside other tensions such as between panel and page, or form and materiality. ${ }^{26}$ As can be seen, transmediality of comics has been explored by multiple academics aside from Żaglowski, such as Jared Gardner who draws attention to the transmediality of early and modern comics enhanced by the role of new multimodal media; it is also here that he mentions the concept of transmedial crossing

${ }^{17}$ Ibid., p. 25.

18 Ibid.

${ }^{19}$ W. Eisner, op. cit., p. 13.

${ }^{20}$ Ibid., pp. $12-16$.

${ }^{21}$ H. Jenkins, Convergence Culture: Where Old and New Media Collide, New York-London 2006, pp. 20-21.

${ }^{22}$ T. Żaglowski, Night of the Owls: Defining Transmediality as an Analytical Tool for Reconstructing Comic Book Mythology, "Przegląd Kulturoznawczy" 2017, nr 33 (3), p. 373. Żaglowski also mentions Marie-Laure Ryan's and Jan-Noël Thon's approaches to transmediality, noting Ryan's as more narrative and Thon's as cognitive.

${ }^{23}$ Ibid., pp. 372-389.

${ }^{24}$ L. Etter, G. Rippl, Intermediality, Transmediality, and Graphic Narrative [in:] From Comic Strips to Graphic Novels: Contributions to the Theory and History of Graphic Narrative, eds. D. Stein, J. Thon, Berlin-Boston 2013, pp. 191-217.

${ }_{25}$ T. Żaglowski, op. cit., p. 377.

${ }^{26}$ Ibid., pp. 377-378. 
between image and text in comics that Żaglowski derives from him. ${ }^{27}$ Other academics pointing out the connection between transmediality and comics include the previously mentioned Gabriele Rippl and Lukas Etter, who discuss graphic narratives as "transmedial phenomena due to their remediation potential. . . also intermedial narratives based on words and images that collaborate to relate stories". ${ }^{28}$ Here, remediation originates from Marie-Laure Ryan's concept of the term that is synonymous with transmedial storytelling ${ }^{29}$ and which Rippl and Etter adequately summarise as: "a story that told in one medium can later be retold in a different medium, but due to medium-specificities, the result will never be the same". ${ }^{30}$

Colin Harvey also delves intro the transmediality of comics; framing comics, among other media, within transmedia storytelling, emphasizing that they may contain analogue and digital elements (like webcomics), as well as be understood in isolation or across various media. ${ }^{31}$ It can be therefore seen that webcomics are an embodiment of transmediality, as aside from their analogue comic medium features, such as e.g. the concept of the page, panel, or the gutter, one can additionally observe webcomics' digital and online features. Furthermore, similarly like printed comics, webcomics function in complex environments where not only word and image intertwine on an intermedial level, but also which include websites, background stories, and technological adjustments that heighten the reader's experience on a transmedial level.

Therefore, as phenomena related to transmediality, comics take advantage of the innovations and forms at hand, employing different devices which, in the mind of the author, serve to enhance the meaning and presentation of the work. In the past, this could have meant choosing certain materials, such as woodblocks, plate engravings or long parchments. On the other hand, in the twentieth century this could have meant making a choice between a serialized, three-panel syndicated comic strip in a newspaper (such as Peanuts by Charles M. Schulz or Garfield by Jim Davis) or the superhero comic book format used by DC and Marvel. In his book Comics versus Art, scholar Bart Beaty makes his reader acutely aware of how a comic creator can occupy a space at a given moment in time. ${ }^{32}$ This takes place alongside a discussion of the relationship between comics and art, where for instance, Beaty brings up Andy Warhol's works, discussing its contrasts and comparisons with mass-produced comic books. ${ }^{33}$ Therefore, the comic medium is susceptible to changing forms at a given time.

27 J. Gardner, Film + Comics: A Multimodal Romance in the Age of Transmedial Convergence [in:] Storyworlds Across Media: Toward a Media-Conscious Narratology, eda. M.-L. Ryan, J.-N. Thon, Lincoln-London 2014, pp. 193-210.

28 L. Etter, G. Rippl, op. cit., p. 191.

29 M.-L. Ryan, Introduction [in:] Narrative Across Media: The Languages of Storytelling, ed. M.-L. Ryan, Lincoln-London 2014, pp. 1-40.

${ }^{30}$ L. Etter, G. Rippl, op. cit., p. 203.

31 C. Harvey, A Taxonomy of Transmedia Storytelling [in:] Storyworlds Across Media..., op. cit., pp. 278-294.

32 B. Beaty, op. cit., p. 260.

33 Ibid., pp. 191-203. 
It is perhaps then unsurprising that in recent years comics discourse has shifted towards the function of the medium within the digital, notably considering the role of the Internet in particular. McCloud was one of the first scholars to address this matter in Reinventing Comics, where he discussed how computers and the proliferation of online resources have begun to influence the comic medium. ${ }^{34}$ Furthermore, McCloud expressed disappointment at the fact that online comic creators did not experiment with developing technology and that they did not take advantage of the possibilities that both the Internet and the computer had to offer: "[Many] online comics are still no more than repurposed print at heart" ${ }^{35}$ Here McCloud is specifically referring to the digitization of comics - be they comic strips, graphic novels or comic books - which simply function as digital works that are very similar to their printed counterparts.

Such digital comics are presented in Ernesto Ramírez's taxonomy. Therein he details the fact that many online webcomics fall into the category of "digital comics" - comics that simply exist and function in a digital environment, while continuing to adhere to the standards of printed comics. ${ }^{36}$ Ramírez's taxonomy differentiates digital comics from webcomics, an important distinction because, while both can exist digitally and online, webcomics are "meant to be distributed and read on digital platforms online" and "make use of the possibilities of Internet Technologies such as HTML, Flash, etc.". ${ }^{37}$ As such, webcomics are primarily meant to function online, taking advantage of technology.

In order to emphasize the difference between webcomics and digital comics, McCloud coined the term "infinite canvas." The primary concept underpinning the term was centered on the notion of treating the computer screen as a window, therefore not subjecting the comic form in the digital space to the restraints that are necessary in print, ${ }^{38}$ for example the size of the page or the limitations of the three-panel comic strip. McCloud further expanded the definition of the infinite canvas on his website, stating that pages should be optional and that "the advantages of putting all panels together on a single canvas are significant and worth exploiting". ${ }^{39}$ In this way, McCloud encouraged creators to see the computer as a valuable technological development that could aid in the creation of experimental webcomics. These need not adhere to commonplace printed forms and could incorporate additional features characteristic of the new media, such as being able to click on interactive elements, animation, music and sound effects.

It is important to mention that the term "webcomics" initially referred to any online comics, and even today it continues to be used as an umbrella term for all comics that are digital or that exist solely online. The first "webcomics,"

34 S. McCloud, Reinventing Comics: How Imagination and Technology Are Revolutionizing an Art Form, New York 2000.

35 Ibid., p. 203.

36 E.F.P. Ramírez, The Comic Book in the Age of Digital Reproduction [PhD diss.], London 2010, p. 228.

37 Ibid., p. 229.

38 S. McCloud, Reinventing Comics..., op. cit., p. 222.

39 Idem, The 'Infinite Canvas', "Scottmccloud"2009, http://scottmccloud.com/4-inventions/canvas (access: 23.02.2021). 
which appeared in the mid-1980s, resembled either the newspaper comic strip or the comic book and did not include additional features like animation or infinite scrolling, mostly due to the technological constraints of the time. One of the first recorded webcomics, T.H.E. Fox by Joe Ekaitis, was first published online in 1986 and resembled the classic three-panel newspaper comic strip. Similarly, Where the Buffalo Roam (1987) by Hans Bjordahl was a few panel strips drawn on paper and then scanned onto a computer. While variations of the comic strip and the comic book continued to appear online up until the early 2000s, few titles adhered to the now understood definition of webcomics.

It was for this reason that McCloud's insight about the infinite canvas ${ }^{40}$ had such a profound impact on the webcomic form. As webcomic author Shaenon $\mathrm{K}$. Garrity notes in her article on the history of webcomics, "Reinventing Comics ushered in a flowering of webcomics experimentation". "She further points out that along with the appearance of new digital tools and the development of computer technology, creators became more aware of the possibilities that lay before them. Currently, webcomics take much greater advantage of new media, combining unorthodox subject matter with selected features that can only be implemented online, such as music, animation or sound effects. Even if a webcomic does not incorporate visual enhancements or take advantage of the creative possibilities of the online form, it can be still classified as a webcomic due to its dependence on its online environment and its significant hyper textuality. As Ramírez points out in his taxonomy, webcomics function alongside other features often found in a browser page, such as forums, blogs, online shops, comment sections and so forth. ${ }^{42}$ Stu Campbell's webcomics do not fall into this sub-category; rather, they take advantage of the webcomic form by using technological functions that can be incorporated through an Internet browser.

With that said, it is therefore necessary to differentiate between webcomics that function in an online environment but that do not incorporate additional technological features, and those that do. Ramírez duly notes the following about contemporary webcomics: "In spite of other creative possibilities, many of them are based on sequential hyperlinked comic strips comprising a longer narrative". ${ }^{43}$ Yet they are still classified as webcomics, as should they be printed, a significant portion of the reading experience would be lost, an experience that is linked to the Internet browser.

A popular example of such a webcomic could be, for instance, Gunnerkrigg Court by Tom Siddell. Siddell's comic book is published in a traditional printed format, but it is also hosted on a website that includes a multitude of aspects that influence the reading experience. These include a Comments and Trivia section, an online shop, a blog, links to crowdfunding sites and so forth. At the same time, Gunnerkrigg Court has printed editions for sale, which, while removed from the

40 Idem, Understanding..., op. cit.

41 S.K. Garrity, The History of Webcomics, "The Comics Journal" 2011, http://www.tcj.com/thehistory-of-webcomics (access: 20.02.2021).

42 E.F.P. Ramírez, op. cit., p. 229.

43 Ibid. 
online context, would not directly impede the reader in their enjoyment and interpretation of the story. This example contrasts with Campbell's works; all three titles discussed here are embedded in online pages, with digital features that could not be readily translated to a printed form. A printed version could perhaps be painstakingly created, but it would become a mere adaptation, far removed from the original.

Comics scholar Josip Batinić talks about such webcomics at length, referring to them as "enhanced webcomics." For Batinić:

Enhanced webcomics refer to all of these different varieties of webcomics which are "enhanced" by the use of digital properties, tools, and effects and as a part of their form, and which thus attempt to "enhance" user experience. ${ }^{44}$

Batinić goes on to call such webcomics a new media form, one that actively appropriates technological advancements as opposed to non-enhanced webcomics. Therefore, enhanced webcomics can be classified as medium specific works. The concept of medium-specificity is not new in academia, and has become a relevant query to electronic works which are intertwined with their digital affordances. For instance, N. Katherine Hayles regularly brings up Media-Specific Analysis (MSA) in her body of works, ${ }^{45}$ an analytical method which relies on drawing attention to the medium of a given work, and how said medium influences the form and content of a work. Hayles frames MSA within the digital, noting how electronic literature tends to build on expectations formed by the print medium, modifying and reworking them to fit its digital medium. ${ }^{46}$ This is what can be observed within the context of enhanced webcomics, which retain features associated with printed comics, such as panels and gutters, but are modified to incorporate web and browser affordances. Furthermore, Hayles emphasizes that MSA: "recognizes that all texts are instantiated and that the nature of the medium in which they are instantiated matters". ${ }^{47}$ Essentially, the medium is brought to the foreground and its role underscored within the reading process, an influence that can be noticed in Batinić's definition of enhanced webcomics, which focuses on the digital properties inherent to the form. It bears mentioning the enhanced webcomics require a substantial amount of effort in their creation; as previously mentioned by both Ramírez ${ }^{48}$ and McCloud, ${ }^{49}$ it is for this reason that most webcomics are non-enhanced, as they are often self-published with minimal effort put into the incorporation of technological features. This is evidenced by the number of selfpublishing websites available to creators, such as Tapas or Webtoons, which allow

44 J. Batinić, 'Enhanced Webcomics': An Exploration of the Hybrid Form of Comics on the Digital Medium, "Image \& Narrative" 2016, No. 17 (5), p. 81.

${ }^{45}$ N.K. Hayles, Electronic Literature: New Horizons for the Literary, Notre Dame 2008; eadem, Print is Flat, Code is Deep: The Importance of Media-Specific Analysis, "Poetics Today" 2004, No. 25 (1), pp. 67-90; eadem, Writing Machines, Cambridge-London 2002.

${ }^{46}$ Eadem, Electronic Literature..., op. cit., p. 4.

${ }^{47}$ Eadem, Print is Flat, Code is Deep..., op. cit., p. 67.

${ }^{48}$ E.F.P. Ramírez, op. cit.

${ }^{49} \mathrm{~S}$. McCloud, Reinventing Comics..., op. cit. 
for ease of publication but limit technological creativity. By contrast, Campbell's works stand out thanks to their enhanced and experimental characteristics.

When referring to the multiple opportunities that experimental literary digital media can take advantage of, it is useful to mention the concept of affordances (one that I will make use of in the following analysis). The term originally derives from psychologist James L. Gibson, who created the first comprehensive definition of the term in his book first published in 1979, The Ecological Approach to Visual Perception. According to Gibson's definition, affordances refer to certain possibilities of an individual within an environment. ${ }^{50}$ In contemporary academia, the term affordances has been largely used within the context of digital, electronic and interactive media, such as in Michael Mateas' (2001) article on digital interactive drama and games. ${ }^{51}$ For the purposes of this article, Paola Trimarco's explanation of affordances in her book Digital Textuality is most relevant, as it is explained within a modern, digital, and literary context as: "the possibilities and constraints for action [of digital media and text] in various digital spaces". ${ }^{52}$ She then goes on to give multiple examples of digital media that operate within certain constraints but that take advantage of select opportunities only available through new media. Therefore, affordances refer to whatever capability a certain piece of digital creation has; for instance, a webcomic created through Flash software would be easy to access online within a browser, but it would be impossible to replicate in static form. As we shall see, Campbell takes advantage of the opportunities afforded by the digital realm within the comic medium, not just by adapting these features to the online comic form but also by striving to intertwine these features with the work itself in a meaningful way.

\section{Stu Campbell and His Experimental Digital Works}

Stu Campbell, more widely known by his artistic alias Sutu, is an Australian writer, interactive designer and illustrator who, as he states on his own website, "uses art and technology in new ways to tell stories". ${ }^{53}$ In 2008 he created his first project Nawlz, a cyberpunk webcomic that ultimately influenced the creation of a series of personal projects, among which were Modern Polaxis and These Memories Won't Last. Campbell often states that he is interested in the way technology can be used to create powerful narratives where it is a key element and not an empty addition. ${ }^{54}$ In this way, Campbell stands out as a webcomic creator who experiments with digital technology and who strives to approach new subject matter within the online comic form. The following analyses will describe these endeavors in greater detail.

${ }^{50}$ J.J. Gibson, The Ecological Approach to Visual Perception, New York 1979/2015, pp. 118-136.

${ }^{51}$ M. Mateas, A preliminary poetics for interactive drama and games, "Digital Creativity" 2001, No. 12 (3), pp. 140-152.

${ }_{52}$ P. Trimarco, Digital Textuality, London 2015.

${ }_{53}$ S. Campbell, About, Sutueatsflies, http://www.sutueatsflies.com/about (access: 22.07.2018).

${ }^{54}$ Submarine Channel, Profile: Sutu Interactive Comics Creator, "Vimeo", https://vimeo. com/175204833 (access: 22.07.2018). 


\subsection{Nawlz}

Campbell describes Nawlz as an "experimental interactive cyberpunk adventure series," which he considers to be one of his most important achievements. ${ }^{55} \mathrm{Ar}-$ tistic direction, animation and plot writing were done by Campbell, while sound design was largely done by creators Speakerwrath and Sinuso Dial. Nawlz ran until 2009 on its official website, and in 2011 it was re-released for the iPad, with additional animations available via touchscreen. ${ }^{56}$ The work was released episodically, and the piece can now be considered episodic by nature.

The titular Nawlz is the name of the city in the webcomic, which in turn comes from the combination of "night" and "sprawl". ${ }^{57}$ The main plot follows Harley Chambers, a cyber-graffiti artist who spends his days covering the city with his "virtual reality" holographic graffiti - within the webcomic this is described as "casting Sleeper Reals." Harley's Real is called a Sleeper Giant; it is also his avatar within the virtual world, an artistic rendition of the character himself. Harley navigates the city, intent on marking the entire place with his trademark graffiti, but he gradually begins to fall into the trap of mistaking the virtual world for reality.

This brief summary establishes Nawlz as a futuristic work, one that makes use of cyberpunk neologisms and illustrations in order to establish its setting and mood. As such, it is not surprising that Campbell decided to make use of the comic medium in online form by creating an enhanced webcomic that reflects the subject matter present in Nawlz: the dangerous blurring of boundaries between the real world and the imagined virtual one through the use of a telepathic internet. Throughout Nawlz, the reader is greeted with a clear codification of the virtual world in contrast to the real one. The virtual world is portrayed as vibrant and exciting, colorful and kinetic, containing numerous attractions, pleasures and amusements. By contrast, the real world is accentuated by dark colors, neon blues and a general lack of action and excitement. Campbell magnifies the difference between the two by allowing the reader to interact with images, panels and speech bubbles.

When the reader drags their cursor on selected "hotspots" marked by symbols or arrows, they are greeted by, for example, overlapping images of the virtual world, additional text, animations, sound effects and music, all of which influence the plot and simultaneously the aesthetic presentation of the webcomic at hand. For instance, in the first section of Nawlz, the reader encounters an image of a whale and the interface of a music player. Gliding the cursor onto the whale triggers ocean sounds, while clicking on the music player triggers a burst of whale song. Music and sound effects play a vital role within Nawlz, as these features control the atmosphere and often irrevocably shift the mood, placing emphasis on

55 S. Campbell, I'm a Restless Nomad: Interview by Rob Ford, "Favorite Website Awards", https:// thefwa.com/interviews/stu-campbell (access: 22.07.2018).

56 Idem, About Nawlz, "Nawlz", http://www.nawlz.com/hq/about (access: 20.08.2018).

57 Idem, SUTU Campbell: Interview with Zucca Blog Zine, "Zucca Blog Zine”, http://www.zuccablogzine.com/SUTU-CAMPBELL (access: 20.08.2018). 
certain plot points. When Harley chases after a strange, headless Real, the music shifts to an upbeat, energetic tempo, but when Harley is researching how whales look, we hear ambient oceanic sounds in the background.

In another example of how Campbell incorporates and uses new media affordances within the webcomic format, the reader is greeted by an overarching illustration of the city. However, when a hotspot is clicked, an imposing, gigantic octopus hologram appears with its tentacles wrapped around the buildings, a metaphor for how the city is trapped by virtual reality. The reader is moreover encouraged to thoroughly explore subsequent images by either clicking or dragging the cursor onto hotspots to obtain more information and hidden clues related to Harley's ventures. Such effects would not be possible in the printed comic form, but as an enhanced webcomic, Nawlz permits the reader to actively search for clues thanks to Flash technology. Subsequently, believable immersion occurs, as the reader is reading a comic in a form that reflects the subject matter of the plot itself.

Campbell's use of browser and web affordances does therefore emphasize the artistic and literary direction of Nawlz; the comic medium is translated into an online interactive format in order to portray how digital information can overlap with and negatively influence the real world. Bright, flickering imagery or sudden sounds and animated movements create an atmosphere of confusion, the blurring of boundaries at a concerning pace. This lasts up until the climax of the first season of Nawlz, which depicts a horrific train crash. The event was at first implied to have happened only in the virtual world, but it is later proved that it occurred in the real world too. The blurring of boundaries is made stronger by one of the webcomic's recurring phrases: "distortion reigns supreme." These words haunt the reader in different ways: as a background sign, a hovering digital image or even a distorted sound. In an interview, Campbell mentions being influenced by the paranoid fiction of Phillip K. Dick and William S. Burroughs, further explaining not only his choice of form but also his particular use of affordances within Nawlz. ${ }^{58}$

Aside from the use of affordances, Campbell pushes the webcomic form to its limits by applying the concept of the infinite canvas. Nawlz is described as follows in its "About" section:

[T] he experimental nature of its delivery format is what makes Nawlz most unique, with traditional comic panels replaced by animated frames that play out on a panoramic, interactive digital canvas. ${ }^{59}$

In Nawlz, panel arrangement is horizontal, and while there are panel formations, they are often irregular and jumbled, sometimes shifting in shape and size depending on the reader's actions. Some illustrations are not even confined to a panel but spread throughout the horizontal canvas. As such, Nawlz takes full advantage of the infinite canvas introduced by Scott McCloud, rolling out illustrations and panels onto a seemingly never-ending horizontal digital scroll. While it

58 Idem, Polaxis: An Interview with Sutu by Oscar Russell, "WeTheNerdy", http://wethenerdy. com/polaxis-an-interview-with-sutu (access: 7.07.2018).

59 Idem, About Nawlz, op. cit. 
is not unusual for printed comics to have a spread, or a longer, horizontal panel arrangement, what make Nawlz stand out in its online format is how the canvas stretches on until the end of the first season of the webcomic, providing a seamless experience that is not hampered by the constraints of the page.

Interestingly, panel progression does not always adhere to the reader's desires; in some instances, Campbell implements authorial control of reading pace through the use of Flash software and hyperlinking, either speeding up panel progression when there is sudden action, or slowing it down when the webcomic demands reflection. An example is when Harley is nearly run over by a vehicle; the subsequent panels quickly load onto the canvas and are accompanied by the sound of screeching tires, creating a sense of sudden urgency. Such a display is beyond the control of the reader and in the hands of the author; therefore, Campbell's enhanced webcomic partially deprives the reader of control while at the same time giving it back through hypertextual interaction. This dichotomy, created using affordances, is interesting in how it emphasizes the difference between perceived and true control over one's actions, reflecting the theme at hand in Nawlz itself.

Nawlz is, as we have seen, engaging in its use of affordances; Campbell effectively uses online technology to impact the reading experience, creating a work that is deeply multimodal and "aligned with representational and communicative need" ${ }^{60}$ In this way it becomes a truly experimental new media work. At the same time as Nawlz retains its identity as an enhanced webcomic, using such features as animation and sound, it does not forgo elements that ensure it belongs to the comic medium, such as panels or speech bubbles.

\subsection{These Memories Won't Last}

Unlike the complex and lengthy Nawlz, These Memories Won't Last is a much simpler webcomic. Published in 2015, it is a personal, biographical piece that tells the story of Campbell's own grandfather, Ladislav Szoke. Even though These Memories Won't Last is short, it is regarded as one of Campbell's best works and was nominated for an Eisner Award in 2016. Like Nawlz, These Memories Won't Last employs numerous affordances, such as music and animation, in order to create a moving and realistic narrative that is grounded within the webcomic medium.

These Memories Won't Last recounts the story of Szoke's battle with dementia and its growing severity; the illness, for instance, is the cause of psychotic episodes during which Szoke's memories of World War II are mixed up with the present. However, These Memories Won't Last is partially autobiographical, as Campbell is present within the webcomic as well, serving as the narrator who relays his grandfather's troubles to the reader. It is important to note that while the work is predominately heartbreaking, Campbell intersperses humorous anecdotes throughout the webcomic, making for an emotionally balanced narrative. Reviewer Nicole Ntim-Addae flags how "Sutu interjects happy memories of his

\footnotetext{
${ }^{60}$ G. Kress, Literacy in the New Media Age, New York 2003, p. 6.
} 
grandpa throughout his commentary on his decline," which results in the short webcomic skillfully capturing an entire lifespan. ${ }^{61}$

While the subject matter is more delicate than Nawlz, Campbell adapted it into the form of an online comic in a way that captured the tragedy of his grandfather's life: "not only is the content a reference to the fragility of memory and the condition of dementia, but the medium through which the story is presented" ${ }^{62}$ Just as in Nawlz, Campbell makes use of the infinite canvas for his webcomic. However, he does so in a vertical rather than horizontal manner: "in the browser-based experience, the user navigates through the story by scrolling [up] a seemingly endless white canvas". ${ }^{63}$ As such, Campbell creates a canvas that is not interrupted by page breaks, allowing, as with $\mathrm{Nawl}$, for a seamless reading experience that stands out in its experimentation and in its unorthodox presentation.

In These Memories Won't Last, the panel arrangement is unique. The pale blue panels and illustrations are distributed along the length of the white canvas and are visually connected by a thick worn rope of the same color. A thin red string runs parallel to the blue rope, flowing vertically upwards and shifting into words that constitute narration. The two ropes contrast with each other: the red string represents Campbell's narration, while the pale blue rope represents Szoke's mind. The reader is to follow the red string by scrolling upwards, while in opposition to it, the pale blue rope, the thicker of the two, flows downwards, occasionally knotting and fraying at its edges, or even tangling around characters or objects. Campbell does then use an affordance based on browser scrolling to contrast a young mind with an old one; while the red string is sharp and clear, it is also thin, meaning it is not as experienced or burdened as the older mind. Such movement is brought about by the reader's interactive engagement with the webcomic, emphasizing the theme of memory loss and aging in a poignant way.

The scrolling affordance enabled by the web browser is not the only way Campbell addresses these crucial themes in These Memories Won't Last. Like in Nawlz, Campbell makes use of sound and music to accentuate situations or actions in the webcomic; for example, the melancholic music and the creaking of the old rope can be heard when Campbell's grandfather has trouble recollecting certain memories, just as joyful music can be heard during the telling of amusing anecdotes. Designed and composed by Lhasa Mencur, the sounds and music "gracefully accentuat[e] the mood between playful and melancholic ... [adding] to the emotional impact of the narrative" ${ }^{64}$ Aside from music, animation is incorporated as well. Some is contained within panels, its main purpose to emphasize important events that occur within the webcomic. One of these instances is when

${ }^{61}$ N. Ntim-Addae, These Memories Won't Last, "TheWebcomicPolice" 2016, https://web.archive. org/web/20160612052559/http://www.webcomicpolice.com/2016/05/these-memories-wont-last.html (access: 22.07.2018).

${ }^{62}$ These Memories Won't Last, "Future of Storytelling", https://futureofstorytelling.org/project/ these-memories-won-t-last (access: 1.09.2018).

${ }^{63}$ Docubase, These Memories Won't Last, "DocubaseMIT" 2015, https://docubase.mit.edu/project/ these-memories-wont-last/ (access: 22.07.2018).

${ }^{64}$ Ibid. 
Szoke is first hospitalized; Campbell utilizes animation to vividly portray a war flashback that triggers a psychotic episode, bringing into the webcomic a sense of importance and realism.

However, the most poignant instance of animation occurs throughout the entire webcomic. When scrolling through the canvas, a fog-like animation gradually obscures it: "as you swipe through the story, it starts to fade away, and this gesture replicates the mental illness [my grandfather suffered from]," as Campbell explains. ${ }^{65}$ What is more, it is not possible to scroll back to re-read a portion of the narrative, as the longer the reader lingers on a fragment, the more obscured it becomes: "if the user decides to scroll back, s/he only finds a white cloud, where the stories used to reside". ${ }^{66}$ Campbell says that the decision to include the fog was an effort to directly portray the frustration of memory loss:

$[T]$ his mechanism creates a sense of urgency to read the story before times runs out. This format also corresponds to my grandpa's predicament, every day he is falling deeper into dementia and all his memories are becoming lost (Starr, "Interactive Comic" 2016). ${ }^{67}$

The effect created is experimental but successful in its implementation, demonstrating how Campbell uses affordances enabled by new media in his digital storytelling.

\subsection{Modern Polaxis}

Unlike Nawlz and These Memories Won't Last, Modern Polaxis (2014) is a threefold AR sci-fi work: to experience it, the reader needs the printed comic book, an iPhone or iPad, and an app to scan the pages of the booklet. While Modern Polaxis is more experimental in form than the average webcomic, it will be considered for our purposes an "enhanced webcomic" according to Batinić's typology. This is because AR depends on adding a computer-generated and online-supported visual layer upon the real world, which in this case is the printed comic book itself. AR drastically alters the perception of the recipient; in Modern Polaxis, scanning the pages of the comic book causes additional text, images, animation and even music to appear on the device screen, which in turn become integral parts of the narrative. Reviewer Steven Forbes describes the work as follows: "like magic, images and sounds almost leap off the page at you as you get a better understanding of what you're reading". ${ }^{68}$ Modern Polaxis skillfully incorporates new media and has established itself as a unique experimental work that was one of the first to use contemporary AR technology for explicitly narrative means.

65 Submarine Channel, op. cit.

${ }^{66}$ Docubase, op. cit.

${ }^{67}$ M. Starr, Interactive Comic Explores the Heartbreaking Frailty of Memory, "CNET" 2016, https://www.cnet.com/news/interactive-comic-explores-the-heartbreaking-frailty-of-memory (access: 10.08.2018).

68 S. Forbes, Review: Modern Polaxis, "Jaycrowcomic" 2015, https://drive.google.com/file/ d/1fQ8ksC7mMy81XQ15_VzkTrfAsQwQNP5d/view?usp=sharing (access: 23.02.2021). 
Even before its release, Modern Polaxis was recognized as a groundbreaking experimental work. ${ }^{69}$ This was mostly due to Boomcore, the innovative program that Campbell and programmer Lukasz Karluk worked on together and integrated into the Modern Polaxis application to create the desired AR effect. Consequently, Campbell was able to produce a piece that worked in conjunction with very recent technology in an effective way, while simultaneously not alienating the reader.

Indeed, despite its complex form, Modern Polaxis is easy to follow. The printed comic book form gives the reader a sense of linear direction, while the app allows them to access the non-linear hidden elements. In their article on AR narrative, MIT scholars talk about the challenges of incorporating a familiar point of reference within an AR model; striving for complete immersion and elimination of any boundaries would only result in confusion and a lack of recognition. ${ }^{70}$ With Modern Polaxis, Campbell not only make use of said boundaries but incorporates them into the narrative, using the traditional comic book form as a basis for interacting with modern AR technology. As Shilkrot et al. (2014) point out with regards to AR narrative, "controlling story progression according to an overarching narrative, and the level of agency the user has over the story world is a key element in a compelling interactive narrative, to support immersion and belief". ${ }^{71}$ Campbell successfully achieves this by combining a tangible printed medium with a virtual one, both of which allow the user to control the speed of consumption in a logical manner due to the engaging narrative.

Furthermore, the narrative of Modern Polaxis is closely connected to AR technology and its affordances. It tells the story of Polaxis, a paranoid time traveler who is certain that our world is merely a projection (the "Intafrag") that is patrolled by agents from another dimension. Determined to find the projectionist and escape the agents, Polaxis conceals his daily logs, theories and investigations within a journal that can only be accessed through AR, the very same technology that the reader uses to access the story itself. This is not a coincidence. As Campbell emphasizes, the AR affects the page and consequently the reading experience: "you don't get the full story unless you read the secret journal [hidden with AR]" (qtd. in Thomas 2017). Modern Polaxis is therefore meta-textual. Aside from the inclusion of AR, the printed comic book is spiral bound and has the appearance of a journal. It is written in the first person as if one were truly reading Polaxis' entries. Forbes notes that Campbell took care to make the comic book look like a chaotic journal; the artistically crafted pages contain messy but legible

${ }^{69}$ J. Plafke, The Future of Comic Books is Augmented Reality, and You Can Fund it on Kickstarter, "Geek" 2014, https://web.archive.org/web/20160110173524/http://www.geek.com/games/ the-future-of-comic-books-is-augmented-reality-and-you-can-fund-it-on-kickstarter-1599196/ (access: 22.08.2018); Z. Roberts, Kickstart This: The Augmented Reality Comics of Modern Polaxis, "Comicbook" 2014, https://comicbook.com/blog/2014/07/23/kickstart-this-the-augmented-realitycomics-of-modern-polaxis (access: 23.02.2021).

${ }^{70}$ R. Shilkrot, N. Montfort, P. Maes, nARratives of Augmented Worlds, "2014 IEEE International Symposium on Mixed and Augmented Reality - Media, Art, Social Science, Humanities and Design" 2014, No. 1, pp. 35-42, https://www.computer.org/csdl/proceedings-article/Ismarmashd/2014/06935436/12OmNzw8j8Y (access: 9.01.2019).

${ }^{71}$ Ibid. 
lettering, and the illustrations have been made to look as if they had been drawn by an amateur, ergo Polaxis himself. ${ }^{72}$

With Modern Polaxis, Campbell is fully conscious of the capabilities of technology, using it to create an experimental work that takes full advantage of the comic medium. Batinić himself praises Campbell's efforts and judges the work positively. For him, "The comic offers a balanced compromise between print and digital comics: both the print and the augmented reality components of Modern Polaxis show off the main attributes of the technology and the format they are using". ${ }^{73}$ Modern Polaxis proves to be a well-rounded and intricate work that could herald a new direction for webcomics.

\section{Conclusion}

Nawlz, These Memories Won't Last and Modern Polaxis all contain narratives that directly relate to our modern world, addressing the common themes, concerns and fears that have stemmed from it. In Nawlz, the issue of overwhelming technological dependence is addressed, a theme that is accentuated by the heavily multimodal character of the work, which implements a great number of affordances. These are made possible by online technologies like Flash software, ${ }^{74}$ which in turn is extensively used to incorporate hyperlinking, music, sound effects, animation and interactivity. In These Memories Won't Last, the reader is confronted with the theme of loss and memory, as emphasized by the unique sound design and fog animation. On the other hand, Modern Polaxis creates a journal-based narrative that breaks the so-called "fourth wall," directly raising questions about the truthfulness of our reality. As such, each of these webcomics contain unique subject matter presented in an experimental format that does not regularly occur within the online comic medium; technological elements are implemented into the works and interweaved with the narrative in a meaningful way.

At the same time, Campbell was able to successfully balance the affordances brought on by new media within the comic medium, without allowing for excessive or needless use. Both $\mathrm{McCloud}^{75}$ and Batinić ${ }^{76}$ have expressed concerns about the excessive infusion of digital affordances within webcomics, noting that there are instances where "the final product stops being a comic and becomes

72 S. Forbes, Review: Modern..., op. cit.

73 J. Batinić, Digital Comics: Harder, Better, Faster, Stronger?, "Network Cultures", https:// networkcultures.org/longform/2016/11/21/digital-comics-harder-better-faster-stronger (access: 23.02.2021).

${ }^{74}$ At the time of publishing of this article (after the $1^{\text {st }}$ of January 2021), Flash will have been pulled by Adobe and ceased to be supported by major browsers, effectively hindering access to some of Campbell's works. Such titles like Nawlz can still be accessed through the manual permitting of Flash use on selected browser e.g. Firefox.

75 S. McCloud, Reinventing Comics..., op. cit.; idem, Understanding..., op. cit.

76 J. Batinić, Digital Comics..., op. cit.; idem, 'Enhanced Webcomics': An Exploration ..., op. cit., pp. 80-91. 
a blend of different digital techniques". ${ }^{77}$ However, the works analyzed here avoid this issue, and Campbell incorporates technological elements with seeming ease whilst staying true to the comic medium. It is to be hoped that future writers and artists continue to explore and experiment with webcomics in a similar manner.

\section{References}

Batinić J., Digital Comics: Harder, Better, Faster, Stronger?, "Network Cultures" 2016, 21.11, https://networkcultures.org/longform/2016/11/21/digital-comics-harder-better-faster-stronger (access: 23.02.2021).

Batinić J., 'Enhanced Webcomics': An Exploration of the Hybrid Form of Comics on the Digital Medium, "Image \& Narrative" 2016, No. 17 (5), pp. 80-91, http:// www.imageandnarrative.be/index.php/imagenarrative/article/view/1384/1114 (access: 20.12.2018).

Beaty B., Comics versus Art, Toronto-Buffalo-London 2012.

Campbell S., About, Sutueatsflies, http://www.sutueatsflies.com/about (access: 22.07.2018).

Campbell S., About Nawlz, "Nawlz", http://www.nawlz.com/hq/about (access: 20.08.2018).

Campbell S., I'm a Restless Nomad: Interview by Rob Ford, "Favorite Website Awards", https://thefwa.com/interviews/stu-campbell, last modified October 2012 (access: 22.07.2018).

Campbell S., Modern Polaxis, Sutueatsflies, 2014.

Campbell S., Nawlz. Nawlz, 2008, http://www.nawlz.com (access: 20.08.2018).

Campbell S., Polaxis: An Interview with Sutu by Oscar Russell, "WeTheNerdy", http://wethenerdy.com/polaxis-an-interview-with-sutu, last modified July 16, 2014 (access: 7.07.2018).

Campbell S., SUTU Campbell: Interview with Zucca Blog Zine, "Zucca Blog Zine”, http://www.zuccablogzine.com/SUTU-CAMPBELL, last modified August 2013 (access: 20.08.2018).

Campbell S., These Memories Won't Last, http://memories.sutueatsflies.com, last modified October 2016 (access: 22.07.2018).

Docubase, These Memories Won't Last, "DocubaseMIT" 2015, https://docubase.mit. edu/project/these-memories-wont-last/ (access: 22.07.2018).

Eisner W., Comics and Sequential Art, Tamarac, FL 1985.

Etter L., Rippl G., Intermediality, Transmediality, and Graphic Narrative [in:] From Comic Strips to Graphic Novels: Contributions to the Theory and History of Graphic Narrative, eds. D. Stein, J.-N. Thon,Berlin-Boston 2013, Lincoln-London 2014, pp. 191-217.

Forbes S., Review: Modern Polaxis, "Jaycrowcomic"2015, 13.11, https://drive.google. com/file/d/1fQ8ksC7mMy81XQ15_VzkTrfAsQwQNP5d/view?usp=sharing (access: 23.02.2021).

\footnotetext{
${ }^{77}$ Idem, Digital Comics ..., op. cit.
} 
Gardner J., Film+Comics: A Multimodal Romance in the Age of Transmedial Convergence [in:] Storyworlds Across Media: Toward a Media-Conscious Narratology, eds. M.-L. Ryan, J.-N. Thon, Lincoln-London 2014, pp. 193-210.

Garrity S.K., The History of Webcomics, "The Comics Journal” 2011, 15.07, http:// www.tcj.com/the-history-of-webcomics (access: 20.02.2021).

Gibson J.J., The Ecological Approach to Visual Perception, New York, NY 2015. (Original work published in 1979).

Groensteen T., The System of Comics, transl. B. Beaty, N. Nguyen, Mississippi 2007. Harvey C., A Taxonomy of Transmedia Storytelling [in:] Storyworlds Across Media: Toward a Media-Conscious Narratology, eds. M.-L. Ryan, J.-N. Thon, LincolnLondon 2014, pp. 278-294.

Hayles N.K., Electronic Literature: New Horizons for the Literary, Notre Dame, IN 2008.

Hayles N.K., Print is flat, code is deep: The importance of media-specific analysis, "Poetics Today" 2004, No. 25 (1), pp. 67-90.

Hayles N.K., Writing Machines, Cambridge-London 2002.

Jenkins H., Convergence Culture: Where Old and New Media Collide, New YorkLondon 2006.

Kress G., Literacy in the New Media Age, New York 2003.

Mateas M., A preliminary poetics for interactive drama and games, "Digital Creativity" 2001, No. 12 (3), pp. 140-152.

McCloud S., Reinventing Comics: How Imagination and Technology Are Revolutionizing an Art Form, New York 2000.

McCloud S., The 'Infinite Canvas', "Scottmccloud” 2009, 02, http://scottmccloud. com/4-inventions/canvas (access: 23.02.2021).

McCloud S., Understanding Comics, New York, NY 1993.

Ntim-Addae N., These Memories Won't Last, "TheWebcomicPolice" 2016, 31.05, https:/web.archive.org/web/20160612052559, http://www.webcomicpolice.com/ 2016/05/these-memories-wont-last.html (access: 22.07.2018).

Plafke J., The Future of Comic Books is Augmented Reality, and You Can Fund it on Kickstarter, "Geek" 2014, 14.07, https://web.archive.org/web/20160110173524/, http:/www.geek.com/games/the-future-of-comic-books-is-augmented-realityand-you-can-fund-it-on-kickstarter-1599196 (access: 22.08.2018).

Ramírez E.F.P., The Comic Book in the Age of Digital Reproduction, PhD diss., University College London, 2010.

Roberts Z., Kickstart This: The Augmented Reality Comics of Modern Polaxis, "Comicbook" 2014, 23.07, https://comicbook.com/blog/2014/07/23/kickstart-this-theaugmented-reality-comics-of-modern-polaxis (access: 23.02.2021).

Ryan M.-L., Introduction [in:] Narrative Across Media: The Languages of Storytelling ed. M.-L. Ryan,, Lincoln-London 2004, pp. 1-40.

Shilkrot R., Montfort N., Maes P., nARratives of Augmented Worlds, "2014 IEEE International Symposium on Mixed and Augmented Reality - Media, Art, Social Science, Humanities and Design" 2014, No. 1, pp. 35-42, https://www.computer. org/csdl/proceedingsarticle/Ismar-mashd/2014/06935436/12OmNzw8j8Y (access: 9.01.2019). 
Starr M., Interactive Comic Explores the Heartbreaking Frailty of Memory, "CNET" 2016, 10.01, https://www.cnet.com/news/interactive-comic-explores-the-heartbreaking-frailty-of-memory (access: 10.08.2018).

Submarine Channel, Profile: Sutu Interactive Comics Creator, "Vimeo", https://vimeo.com/175204833 (access: 22.07.2018).

These Memories Won't Last, "Future of Storytelling”, https://futureofstorytelling.org/ project/these-memories-won-t-last (access: 1.09.2018).

Thomas A., Web Comic Maverick Sutu Talks Augmented Reality Comic Modern Polaxis, "Pipedreamcomics" 2017, 27.07, http://pipedreamcomics.co.uk/interview-situ-augmented-reality-in-modern-polaxis (access: 23.02.2021).

Trimarco P., Digital Textuality, London 2015.

Żaglowski T., Night of the owls: Defining transmediality as an analytical tool for reconstructing comic book mythology, "Przegląd Kulturoznawczy" 2017, nr 33 (3), s. 372-389. 